УАK 316.34/.35:336.7

ББК $60.54+65.262$

DOI 10.22394/1682-2358-2018-2-150-156

K.N. Korol, post-graduate student of the History, Philosophy, Political Science and Sociology Department, Saratov Socio-Economic Institute (Branch) of Plekbanov Russian Economic University

\section{YOUTH PREFERENCES OF INNOVATIVE \\ PAYMENT METHODS}

The young people's attitude and perception of innovative methods of payment is considered. The data of the authorial sociological survey "Young People's Preferences Regarding Modern Methods of Payments" is presented. The prevalence of practices of using electronic means of payment: bank cards, electronic payment systems, mobile transfers and crypto-currency is studied.

Key words and word-combinations: youth, digital cash, means of payment, electronic payment facilities, sociology of youth.
К.Н. Король, аспирант кафедрьг истории, философии, политологии и сочиологии Саратовского сочиально-экономического института (филиала) Российского экономического университета имени Г.В. Плеханова (email:korol-govorit.koro@yandex.ru)

\section{ПРЕАПОЧТЕНИЯ МО $О \triangle Е Ж К И$ В ОТНОШЕНИИ COBPEMEHНЫХ СПОСОБОВ ПААТЕЖЕЙ}

Аннотация. Рассматривается отношение молодежи к инновационным методам платежей. Представлены данные авторского социологического опроса по соответствующей теме. Исследуется распространенность практики использования электронных платежных средств банковских карт, электронных платежных систем, мобильных переводов, криптовалюты.

Ключевые слова и словосочетания: молодежь, виртуальные деньги, платежные средства, электронные средства платежа, социология молодежи.

овременные платежные средства все чаще оказываются в центре разАичных Аискуссий. Выдвигаются разные теории о том, что эмектронные платежные средства и электронные Аеньги, ввиду их многофункционацьности, постепенно вытеснят намичные Аеньги. В Аеньгах такой формы заинтересовано не только государство, но и мюАи, веАь на производство наличных Аенег тратятся средства от налогов [1]. Помимо этого, «новая» экономика станет намного 
эффективней, так как Аинамика перемещения денежных среАств увеличится, улучшится контроль за финансовыми потоками, а значит, есть вероятность сокращения неформального сектора.

Изучение предпочтений молодежки в отношении современных способов платежкей обусловлено активным распространением и разнообразностью современных финансовых инструментов. Анализ предпочтений молодежи с позиций соџиологической науки позволит выявить определенные тенденџии их финансового поведения в области данных способов платежей, а также их перспективности. Так, по данным регумярного исследования РосИндекс компании Ipsos Comcon, российская молодежь (более 80\%) активно использует современные финансовые инструменты [2]. Результаты исследования TNS «Сервисы электронных пиатежкей в России» [3] показали, что молодежкь (73\%) активнее Аругих сегментов населения использует электронные деньги и другие электронные средства платежкей. Анализируя данные аналитического центра НАФИ [4], можно сАелать вывоА, что рынок электронных Аенег и иных средств безналичной индустрии в России растет с кажАым годом, и согласно прогнозам данная динамика в среднесрочной перспективе будет только усициваться.

Электронные деньги следует рассматривать как определенный платежный продукт, требующий введения новых средств опматы и хранения. Впервые термин «электронные деньги» появился в 1993 г. в отчете банка Евросоюза, в котором были представлены результаты анациза предоплаченных карт. Согласно отчету Европейского центрального банка, «эмектронные деньги предполагают нацичие технического устройства, на котором хранится электронная информация о денежных средствах, эти деньги можно использовать при расчете с организаџиями, не явцяющимися эмитентами, без вовцечения банковского счета Амя проведения транзакции» [5, с. 7]. В российском законодательстве электронные деньги определяются как «электронные денежные средства ... которые предварительно предоставлены одним кицом (Аиџом, преАоставившим денежные среАства) Аругому мицу, учитывающему информацию о размере предоставленных Аенежных средств без открытия банковского счета (обязанному миџу), Аля исполнения денежных обязательств мица, предоставившего денежные средства, переА третьими

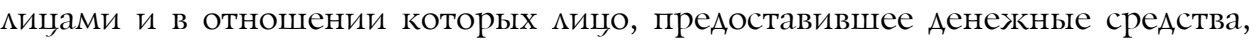
имеет право передавать распоряжения искцючительно с использованием электронных средств платежа» [6]. К самым распространенным электронным средствам платежа можно отнести банковские карты и электронные кошемьки.

Электронные Аеньги отличаются от безналичных денег. Они представцяют собой систему расчетов межау банковскими счетами, то есть безналичные деньги - это форма существования нащионацьной валюты. В свою очереАь, электронные деньги не являются разновидностью Аенег, но могут быть эквивалентны национацьной вацюте (WMR эквивалентен российскому рублю, WMZ - американскому домлару, WME - аналог евро в системе WebMoney), также они могут и не иметь эквивалента, выражкенного какой-мибо наци- 
ональной валютой (например, BitCoin). Некоторые системы электронных платежей требуют обязательной авторизации. K ним относится WebMoney, «Яндекс.Аеньги», Qiwi. Такие системы платежей явмяются персонифицированными. Регистрация в них может, с одной стороны, внушать доверие при манипукяџиях денежными средствами, с Аругой стороны, вызывать опасения «утечки» персональных и паспортных данных.

Существуют и анонимные электронные платежные системы, которые не требуют обязательной идентификации миџа, осуществляющего операцию. K таким электронным деньгам относится криптовалюта BitCoin. Отметим, что в ряде стран обмен и торговця криптовалютами официально разрешены (Япония, США, Швеция, Германия). В Швейцарии, Сингапуре и России не Аают однозначного определения цифровым валютам. Аальнейшее развитие технологии бцокчейн неминуемо приведет к совершенствованию правовой базы в этой сфере. Аецентрализованный характер криптовалют ставит переА государствами сложную задачу по поиску баланса между анонимностью и обеспечением безопасности граждан. Таким образом, экономический термин «электронные деньги», как относительно новый, появияся вследствие эволюџии экономических отношений с появлением электронной коммерции (е-commerce), развивается и расширяется по мере развития указанной сферы.

Возникновение электронных денег обусловлено эволюџией экономики, которая привела к необходимости осуществления расчетов межАу экономическими субъектами, расположенными в совершенно разных географических точках, при этом традиционная банковская система не способна удовлетворять требования, предъявмяемые чрезвычайно динамичной электронной коммерцией как по скорости, так и по гибкости. Как смедствие, электронные Аеньги представляют собой некий договор, в котором объединенные посреАством Интернета участники рынка договариваются о ценности электронной валюты (например, BitCoin зависит исключительно от спроса на него, а WMR, WMZ и WME крепко привязаны к соответствующим национальным валютам).

Несмотря на удобство электронных и безналичных способов расчетов, остаются те, кто предпочитает наличные деньги. Это может быть связано с Авумя явлениями: отсутствием возможности полноценно пользоваться электронными деньгами или вкладыванием опредеменного смысла или ценности в наличные деньги. Распространение безналичных расчетов и использование эмектронных средств платежей обусловливают проблемы понимания современных финансовых инструментов, так как такие денежные средства не имеют материальной формы. Возникают вопросы: возможно ки характеризовать деньги в качестве универсальных и ценностно-нейтральных эмементов, и какая роль отведена им в соџиальном контексте?

Определение роли современных финансовых инструментов невозможно без исследования масштаба их применения, поскольку изучение восприятия современных платежных средств находится в прямой взаимосвязи с их распространением. Аیя объективной картины отношения молодежи к 
инновационным методам платежей автором было проведено эмпирическое исследование на тему «Предпочтения молодежи в отношении современных способов платежей». Общий объем выборки составиц 300 респондентов. Выборка стратифицированная, квотная. Квотируемые признаки - возраст, занятость. Возрастная категория от 20 до 25 мет. Максимацьная статистическая погрешность выборки такого объема при уровне значимости 0,05 составл яет 3,5\%. Исследование было проведено в декабре 2017 г. на территории г. Саратова. В качестве метода исследования использовалось анкетирование.

Результаты исследования показали, что $92 \%$ респондентов имеют в распоряжении банковские карты, 6\% планируют завести, и мишь 2\% отмечают отсутствие необходимости в данном финансовом инструменте. Абсолютное большинство респондентов (85\%) владеют дебетовыми картами, без возможности овердрафта, так как эти карты выданы в рамках «зарплатных» и «стипендиальных» проектов. Несмотря на то что владельцы расчетных карт не были инициаторами их оформления, 65\% респондентов ответило, что им удобней пользоваться банковскими картами, чем наличными денежными средствами. Аанная группа опрошенных активно использует карту Аця безнамичного расчета. Таким образом, наличие банковской карты у большей части респондентов приводит к использованию электронных денежных среАств. Это подтвержжаюют 43\% респондентов, которые пользуются безналичными Аеньгами дия покупок товаров и услуг Аистанџионно. 19\% предпочитают только снимать деньги в банкоматах. 59\% опрошенных от этой группы объясняют свои Аействия тем, что берут с собой только необходимую сумму из-за отсутствия риска потратить больше, чем нужно. По словам опрашиваемых, при походах в магазин с банковской картой велик соблазн потратить все Аеньги.

В 14\% из 100\% вошии те мюди, которые принципиально снимают денежные средства с банковских карт. Как они утверждают, им больше нравится пользоваться наличными деньгами, нежели пластиковыми картами. Аанная категория респондентов отметила, что главные положительные свойства намичных денег следующие: возможность безусловного распоряжения средствами (эмектронные денежные средства имеют ограничения в использовании, например, ежедневный мимит на мобильный перевод или на операции в он-

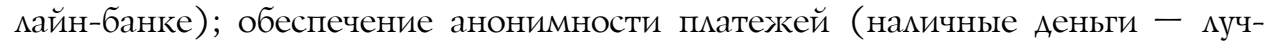
ший «фильтр», защищающий от утечки размичных Аанных плательщика, отследить наличный оборот при разумных тратах невозможно).

Если Аля контроля своих денежных среАств телефон используют $73 \%$ респондентов, то Аля управления своими денежными среАствами - только 58\%. ОАнако 22\% респондентов управляют своими денежными средствами не через мобильные приложения, а через стационарный компьютер или ноутбук, объясняя это неудобством мобильных приложений - 11\%, невостребованностью - 8\%, отсутствием Интернета на телефоне - 3\%. Выявленная ка-

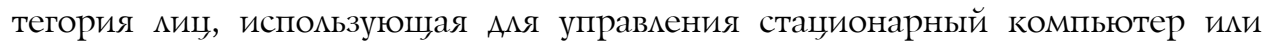
ноутбук ( $8 \%$ ), объясняет свою позицию тем, что в основном Интернетом на 
мобильных приможениях они пользуются Амя общения и развлечений, пока находятся в общественном транспорте или в очередях, где неудобно вводить коды дмя подтверждения платежей. Поэтому им проще осуществить покупку или опкатить ускуги дома.

Респонденты без мобильного Интернета говорят, что для удобства им достаточно перечислять деньги на другие счета через смс-банк и пополнять счет мобильного телефона. Отметим, у трех мюдей из всех респондентов смс-банк даже не подключен. По их мнению, плата за данную услугу банка - мишняя трата Аенег.

Такой высокий коэффиџиент использования эмектронных средств платежей и электронных денег объясняется уверенностью респондентов в безопасности их хранения и использования. Стандартным решением этого вопроса является использование технологии SSL, которая основывается на криптографическом алгоритме RSA. Поэтому у держателей карт формируется доверие к безналичным деньгам. Это связано с взаимосвязью денег и тех соџиальных, политических и культурных условий, в которых происходит денежный обмен. Аенежные транзакции связаны доверием с участниками процесса обмена и системам, в которых они осуществцяются [7]. Формирование доверия к транзакџиям происходит в результате взаимосвязи денег и условий (соџиальных, политических и культурных) денежного обмена.

При переводе денежных средств или оплаты услуг респонденты (58\%) чаще пользуются приложениями и терминалами своих банков. ОАнако 26\% из них дополнительно пользуется фиатными и нефиатными платежными системами. 2\% (6 человек) знали отличие этих двух видов платежжных систем. Ава респондента принщипиально пользуются только фиатными системами, такими как PayPal или Visa Cash. По их мнению, система, которая выражена в государственной валюте и вкмючена в платежную систему государства, более надежна. Электронными кошельками пользуются $72 \%$ опрошенных, $28 \%$ не Аоверяют таким системам расчета. Безналичные интернет - платежки через ониайн-банки используют $59 \%$ респондентов. Среди предпочтений системы эмектронных платежей распределились следующим образом: 18\% - WebMoney, 12\% - «Яндекс.Аенги», 42\% - Qiwi, при этом использование данных систем осуществцяется не из-за принџипиальной позиџии, а из-за сложившейся привычки.

В ходе опроса было выяснено отношение молодых мюдей и к криптовалюте: $30 \%$ респондентов знают о существовании такого технологического явления, при этом отношение к «деньгам будущего» позитивное, $10 \%$ считают, что криптовалюты следует запретить, потому что на них можно анонимно купить запрещенные вещи. 20\% респондентов отметили, что BitCoin оказывает положительный эффект на экономику. $25 \%$ респондентов посчитала криптовалюту «скорее выгодным вложением», но при этом отмечали о наличии высокой волатильности и резких скачках курса. По своей природе BitCoin ближе к анонимным наличным деньгам, чем к персонифицированным безналичным денежным среАствам. 
Итак, современные способы платежей используются большинством молодежи. При принятии решений человек отталкивается от своего восприятия окружающей действительности. Ряд его взглядов на электронные платежные средства благоприятствует проникновению банковских карт и использованию безналичных платежей.

Респонденты, владеющие банковскими картами, отмечают, что основными преимуществами мюбых эмектронных средств платежкей явцяются гибкость, оперативность приема, ликвидность, персонифицированность и безопасность. В то же время два основных преимущества - гибкость и оперативность, могут быть ограничены при отсутствии доступа к Интернету. В этом случае эмектронные средства платежа теряют свою џенность. Безопасность использования и хранения денег - еще один критерий, который определяет форму Аенег. Безусловно, электронные денежные средства не могут быть фальшивыми, но могут выступать в качестве объекта различного рода мошенничества. Среди отличительных черт современных методов платежей респондентами выделяется их виртуальность как основная характеристика и функџиональное значение.

Безналичные и наличные деньги представляют собой разные формы денег. Конкретной ситуации соответствует и форма денег. Реалии современной жизни таковы, что даже на продуктовых рынках (базарах) повсеместно используются платежные терминалы дия оплаты банковской картой.

Кроме того, Аопускаются платежи с использованием приложений онмайн-банка. В условиях, когда молодежкью повсеместно используются размичные новые формы денег и в этом есть потребность, можно утвержАать, что электронные деньги и средства платежа обладают определенным смысцом, который можно интерпретировать в рамках теории соџиальной множественности денег В. Земизера [8]. Востребованность электронных денег взаимосвязана с определенной практикой. При наличии этой практики в повседневной жизни возникает необходимость использования современных финансовых инструментов и наоборот, существующие разнообразные формы электронных платежных средств (карты, мобильные финансы) подтверждают теорию множественности денежных единиц. Потребность использования данных платежных средств возникает как результат распространения современных технологических устройств и Интернета. В то же время безналичные деньги меняют свою ценность для держателя карты, так как счет на карте приобретает характер просто цифр, нежели номинальную стоимость денег, поэтому потратить их проще. Аанное обстоятельство об̆ъясняется различным восприятием транзакций. При оплате по безналичному расчету молодые мюди действительно совершают больше покупок. КогАа денежные среАства обналичиваются, ситуаџия перестает быть проблематичной. Предпочтение наличных денег связано с недостаточной информированностью об использовании приложений и опџий и их особенностях, и отсутствии опыта в использовании подобных инструментов. У $5 \%$ опрашиваемых не возникает потребности в использовании денег, кроме как в их обналичивании. Эта группа мюдей не нуждается в дистанционных заказах или мише- 
на стабильного Интернета, и не всегда имеет возможность расплачиваться картой. Это основные причины преАпочтений использования привычными банкнотами.

В современных условиях электронные деньги и средства платежка явцяются вспомогательным элементом Аля осуществцения экономических операций, но заняли свою нишу в рамках безналичных форм расчетов и явцяются перспективным платежкным инструментом. Развитие электронных денег и платежей видится в их неоспоримых преимуществах, выделенных в ходе исследования, широком внеАрении в повседневную жизнь молодежи.

Инноваџионные методы платежей могут выступать маркером как со стороны общества к индивиду, так со стороны индивида в отношении самого себя, когда он, в силу своего экономического положения, не готов пользоваться разными видами услуг. Вместе с тем использование современных финансовых инструментов позволяет молодежи облегчить проџесс перемещения Аенег во время совершения различных экономических операций. Благоприятное восприятие инновационных методов расчетов вписывается в соџиальный контекст и становится привычной практикой.

\section{Библиографический список}

1. Халина Н.В. Электронные деньги в России: восприятие населением современных способов платежей // Мониторинг общественного мнения: экономические и социальные перемены. 2013. № 2 (114). С. 122-130.

2. Официальный сайт компании Ipsos Comcon. URL: https://www.ipsos.com/ipsos-comcon/ru-ru

3. «TNS Россия» исследовала популярность онлайн-платежей. URL: http://web-payment. ru/article/149/tns-rossija-issledovala-populjarnost-onlajn-platezhej/

4. Официальный сайт Аналитического центра НАФИ. URL: http://nacfin.ru

5. О национальной платежной системе: Федер. закон от 27 июня 2011 г. № 161-Ф3 (в ред. от 18 июля 2017 г.). URL: http://www.rg.ru/2011/06/30/fz-dok.html.

6. Report on electronic money / European Central Bank // European Central Bank. URL: http:// www.ecb.int/pub/pdf/other/emoneyen.pdf.

7. Dodd N. The sociology of money: economics, reason and contemporary society. Cambridge : Polity Press, 1994.

8. Зелизер В. Создание множественных денег // Экономическая социология. 2002. Т. 3, № 4. C. $58-72$. 